\title{
Effects of water quality on aspects of reproductive biology of Cnesterodon decemmaculatus
}

\author{
Micaela Jimena Zambrano ${ }^{\mathrm{a}, \mathrm{b}}$, Gisela Evelín Rautenberg ${ }^{\mathrm{a}, \mathrm{b}}$, Alejo Fabian Bonifacio ${ }^{\mathrm{a}, \mathrm{b}}$, Iohanna Filippi ${ }^{\mathrm{c}}$, \\ María Valeria Améc ${ }^{\mathrm{c}}$ Rocío Inés Bonansea ${ }^{\mathrm{c}}$, Andrea Cecilia Hued ${ }^{\mathrm{a}, \mathrm{b}, *}$ \\ a Universidad Nacional de Córdoba, Facultad de Ciencias Exactas, Físicas y Naturales, Cátedra de Diversidad Animal II, Av. Vélez Sarsfield 299, Córdoba CP 5000, Argentina \\ b CONICET (Consejo Nacional de Investigaciones Científicas y Técnicas), Instituto de Diversidad y Ecología Animal (IDEA), Av. Vélez Sarsfield 299, Córdoba CP 5000, Argentina \\ ' Universidad Nacional de Córdoba-CONICET, Facultad de Ciencias Químicas, Dto. Bioquímica Clínica, Córdoba CP 5000, Argentina
}

\section{H I G H L I G H T S}

- Aquatic biota is chronically exposed to polluted water.

- Water quality affects the reproductive biology of Cnesterodon decemmaculatus.

- Male copulatory organ is a good indicator of environmental degradation.

\section{G R A P H I C A L A B S T R A C T}

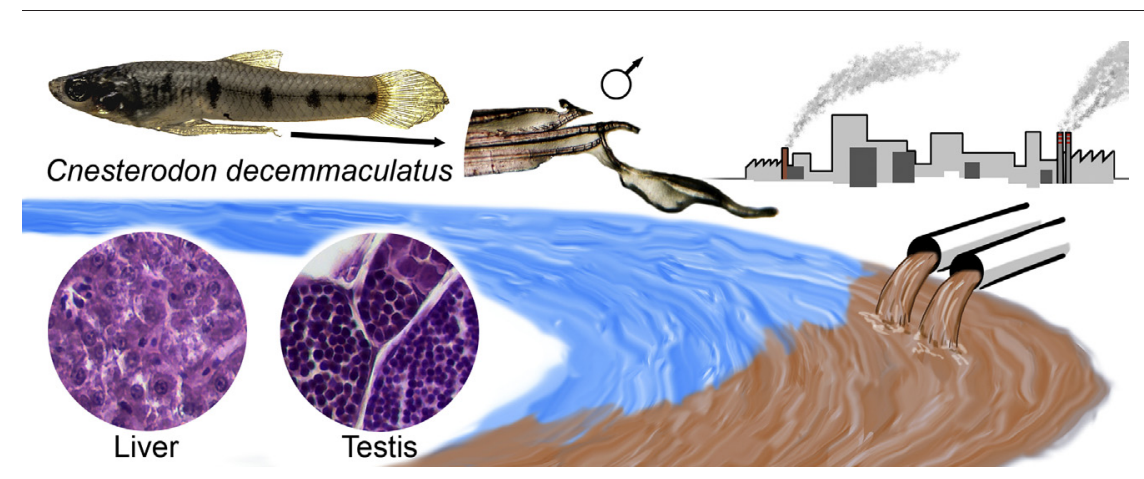

\begin{abstract}
A B S T R A C T
The Suquía River basin (Córdoba, Argentina) is under a strong negative impact due to multiple sources of anthropic pollution. The main goal of our study was to evaluate if variations in the water quality of Suquía river basin affect the reproductive biology of Cnesterodon decemmaculatus and determine if the responses provided by the species can be considered as biomarkers of river quality. This assessment was performed through the measurement of morphological, histological and somatic parameters in adult males collected at four sampling sites during the beginning and the end of the breeding season. The water quality evaluation carried out through the estimation of a water quality index (WQI) and pesticides concentrations in water, revealed a pollution gradient along the studied basin. The same variation pattern was registered for the somatic index. In addition, the analysis of the morphology of the male copulatory organ (gonopodium) showed that individuals collected at Córdoba city had the lowest Gonopodium-Somatic Index (Gonop-SI) value, while those sampled at the most polluted site showed abnormalities in the small structures of the gonopodium. On the other hand, few histological alterations were found in the liver whereas no alterations were found in gonads along the river. The results obtained allowed us to characterize the environmental conditions of the studied basin and demonstrated the water quality deterioration along the Suquía River.
\end{abstract}

(c) 2018 Elsevier B.V. All rights reserved.

* Corresponding author at: Universidad Nacional de Córdoba, Facultad de Ciencias Exactas, Físicas y Naturales, Cátedra de Diversidad Animal II, Av. Vélez Sarsfield 299, Córdoba CP 5000, Argentina.

E-mail address: andrea.hued@unc.edu.ar (A.C. Hued). 


\section{Introduction}

In the last decades, anthropogenic activities have greatly altered freshwater ecosystems around the world. Particularly, in South America, the Pampean region (an extensive area of $750,000 \mathrm{~km}^{2}$ that includes territories of three countries: Argentina, Uruguay and Brasil), is severely affected by the high demographic and agricultural production in this area. The environmental modifications become the Pampean basins into highly altered water bodies (Rodrigues Capítulo et al., 2010). In Córdoba (Argentina) the Suquía River basin, the central landscape element of the province, receives a complex mixture of pollutants from different sources, including agricultural and industrial effluents, urban runoff and effluents from the sewage treatment plant of Córdoba City (Wunderlin et al., 2001; Nimptsch et al., 2005; Contardo-Jara et al., 2009).

The pollution gradient of the Suquía River has been characterized using physicochemical parameters, integrated in a water quality index proposed by Pesce and Wunderlin (2000). Also, it has been evaluated through different approaches involving the measurement of diverse chemical compounds as well as through the status of resident biota (Hued and Bistoni, 2005; Monferrán et al., 2011; Maggioni et al., 2012; Bonansea et al., 2013). In particular, fish individuals have been considered as useful tools in environmental water quality assessment. Their major advantages are that they integrate the direct and indirect effects of stress from altered aquatic ecosystems, and therefore, they manifest the ecological significance of the perturbation (Fausch et al., 1990).

In recent decades, it has been indicated that a wide range of manmade chemicals used for several industrial and household activities disturb the endocrine system of living organisms. These are known as endocrine disruptors (EDs) (Arukwe and Goksøyr, 1998). This diverse group of compounds includes pesticides, plastics, detergents, industrial chemicals and heavy metals. In this regard, numerous studies have shown that sewage discharges from the wastewater treatment plants could contain estrogenic compounds in concentrations sufficient to affect the normal development of the gonads (Tyler et al., 1998; Jobling and Tyler, 2003) and secondary sexual characteristics (Batty and Lim, 1999; Doyle and Lim, 2002).

Since the viviparous poeciliid fish exhibit a hormone-dependent sexual dimorphism they become valuable indicators of the exposure to EDs (Bortone and Davis, 1994). In particular, the ten-spotted live-bearing fish Cnesterodon decemmaculatus (Teleostei, Cyprinidontiformes), a small size native fish whose distribution pattern corresponds entirely to the full extension of the Pampean region (Lucinda, 2005) could be considered as a valuable indicator. The anal fin of male of $C$. decemmaculatus, differentiates into a complex structure called gonopodium, an intromitent organ uses for sperm transfer during copulation. This structure originates from the elongation and modification of anal fin rays 3,4 , and 5 . Its development occurs in response to testicular androgenic hormones at the time of sexual maturation (Rosa-Molinar et al., 1994; Angus et al., 2001). On the other hand, it has been also verified that females of these species can develop gonopodium-like structures under the influence of androgenic hormones (Rosa-Molinar et al., 1994). Therefore, both females and males fish could be affected by the exposure to EDs. These effects have also been demonstrated through histological analysis of reproductive organs (Angus et al., 2001; Wolf et al., 2004; Leusch et al., 2006).

Given the current mentioned situation of environmental degradation along the Suquía River basin, the main goal of the present study was to determine whether water quality alterations could affect different aspects of reproductive biology of the $C$. decemmaculatus. We also determined if the responses provided by this species could be considered as biomarkers of Suquía River quality and for other aquatic resources of an extensive South American area, where $C$. decemmaculatus inhabits.

\section{Materials and methods}

\subsection{Study area}

The Suquía River is a medium-sized hydrological system located in central region of Argentina. The total drainage basin occupies 7700 $\mathrm{km}^{2}$, were $900 \mathrm{~km}^{2}$ correspond to its active drainage area in the Córdoba Province mountain range. The San Antonio and Cosquín rivers are their main upper tributaries, and they end at San Roque Dam. From this dam, the Suquía River starts and flows in western-eastern direction. About $35 \mathrm{~km}$ downstream, from the lake, the Suquía River crosses Córdoba city, a big city with a population of ca.1.5 million inhabitants (INDEC, 2010). On the eastern limit of the city, the Suquía River receives the city sewage discharge generated from the municipal wastewater treatment plant, and then continues downstream Córdoba city flowing across the pampean plane region and finally ends into the Mar Chiquita hypersaline lake, at about $150 \mathrm{~km}$ downstream Córdoba city (Pasquini et al., 2012). The basin flows on a semiarid region characterized by a wet season from December to April that presents an average rainfall of $110 \mathrm{~mm}$ and a dry season from May to November with a mean rainfall of $10 \mathrm{~mm}$. The mean annual historical discharged of Suquía River is 9 $\mathrm{m}^{3} \mathrm{~s}^{-1}$ (Pasquini et al., 2012). The flow regime of the rivers makes up the Suquía drainage network exclusively of pluvial origin, with a marked flow seasonality (Pasquini et al., 2012).

Based on previous studies that clearly demonstrated an environmental quality gradient along the Suquía River basin (Merlo et al., 2011; Monferrán et al., 2011; Rautenberg et al., 2015) four sampling sites were selected (Fig. 1): (1) Puente Zuviria (PZ) on Yuspe River. This site is located $70 \mathrm{~km}$ upstream from Córdoba City $\left(31^{\circ} 14^{\prime} \mathrm{S} ; 64^{\circ}\right.$ $31^{\prime} \mathrm{O}$ ) and it is representative of quasi-pristine conditions (Hued and Bistoni, 2005); (2) Casa Bamba (CB) on Suquía River, 5 km downstream San Roque Dam ( $31^{\circ} 20^{\prime}$ S; $\left.64^{\circ} 24^{\prime} \mathrm{O}\right)$; (3) Puente Cantón (PC) located at Córdoba city downtown ( $\left.31^{\circ} 23^{\prime} \mathrm{S} ; 64^{\circ} 12^{\prime} \mathrm{O}\right)$; and (4) Villa Corazón de María (VCM) on Suquía River, located $14 \mathrm{~km}$ and $5 \mathrm{~km}$ downstream from Córdoba City and Municipal Waste Water Treatment Plant (EDAR), respectively $\left(31^{\circ} 27^{\prime} \mathrm{S} ; 63^{\circ} 59^{\prime} \mathrm{O}\right)$. This river section is characterized by highly contaminated waters (Pesce and Wunderlin, 2000; Hued et al., 2013).

\subsection{Water quality assessment}

Each study sites was sampled at two different times in order to cover the $C$. decemmaculatus breeding season: once during the beginning and the other at the end of the breeding season (November 2014 and April 2015 , respectively). Since 4 sites were sampled along the basin, a total of 8 water samples were taken. In order to characterize the water quality conditions of each site the following physico-chemical parameters were measured: total and faecal coliforms (MPN $\cdot 100 \mathrm{~mL}^{-1}$ : most probable number per $100 \mathrm{~mL}$ ), 5-day biological oxygen demand (5-DBO; $\left.\mathrm{mg} \cdot \mathrm{L}^{-1}\right)$, hardness $\left(\mathrm{mg} \cdot \mathrm{L}^{-1}\right)$, dissolved oxygen $\left(\mathrm{mg} \cdot \mathrm{L}^{-1}\right)$, total and dissolved solids $\left(\mathrm{mg} \cdot \mathrm{L}^{-1}\right)$, calcium $\left(\mathrm{mg} \cdot \mathrm{L}^{-1}\right)$, magnesium $\left(\mathrm{mg} \cdot \mathrm{L}^{-1}\right)$, sulfates $\left(\mathrm{mg} \cdot \mathrm{L}^{-1}\right)$, chlorides $\left(\mathrm{mg} \cdot \mathrm{L}^{-1}\right)$, total phosphorus $\left(\mathrm{mg} \cdot \mathrm{L}^{-1}\right)$ and ammonia $\left(\mathrm{mg} \cdot \mathrm{L}^{-1}\right)$. Analytical methods were performed following APHA (1998) recommendations. From these variables, the Water Quality Index (WQI) proposed for the Suquía River basin by Pesce and Wunderlin (2000) was calculated. Its estimation involves a normalization step, where each parameter is transformed into a $0-100 \%$ scale, where $100 \%$ represents the highest water quality. After that, it is applied weighting factors that reflect the importance of each parameter as an indicator of the water quality. The constructed WQI gives a number that can be associated with a quality percentage. The calculation was as follows: $\mathrm{WQI}=\Sigma\left(C_{i} \cdot P_{i}\right) \mid \Sigma P_{i}$ where $C_{i}$ is the value assigned to each parameter after normalization, $P_{i}$ value range from 1 to 4 , with 4 representing a parameter that has the greatest relevance for aquatic life preservation (e.g. dissolved oxygen), while a value of 1 means that a parameter has a smaller impact on biota (e.g. chloride). 


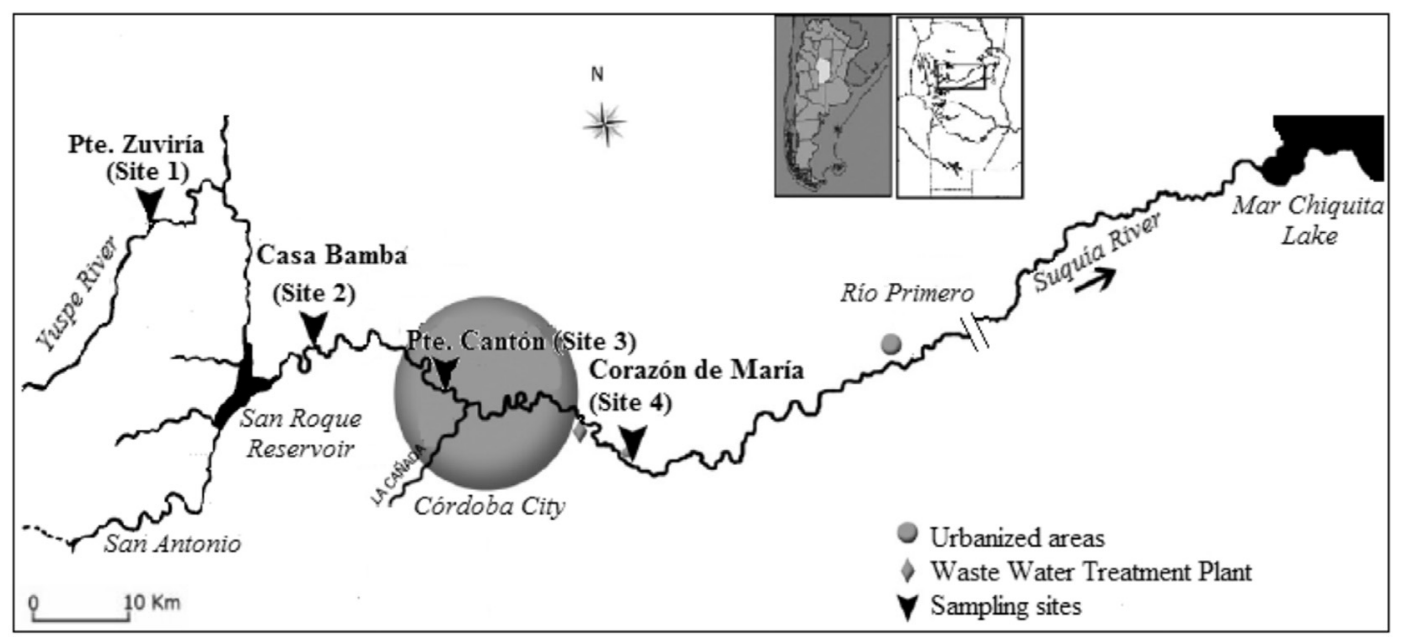

Fig. 1. Study area on the Suquía River basin and location of sampling sites. From: Merlo et al. (2011).

Water samples were also taken to measure the following pesticide concentrations: 4,4' DDD, 4,4' DDE, 4,4' DDT, aldrin, dieldrin, endrin, endrin aldehyde, alfa clordane, g chlordane, alfa hexachlorocyclohexane, $d$ hexachlorocyclohexane, g- hexachlorocyclohexane, chlorbenzilate, chloroneb, chlorothalonil, chlorpyrifos, DCPA (dimethyl tetrachloroterephthalate), cis permethrin, trans permethrin, alpha endosulfán, beta endosulfán, endosulfan sulfate, HCB (hexachlorobenzene), heptachlor, heptachlor epoxide, methoxychlor, propachlor, trifluralin. The limits of detections (LODs) for measured pesticides ranged from 0,2 to $0,5 \mathrm{ng} \cdot \mathrm{L}^{-1}$ and the limits of quantifications (LOQs) ranged from 0,6 to $1,1 \mathrm{ng} \cdot \mathrm{L}^{-1}$. Since Valdés et al. (2014) measured $17 \beta$ estradiol, estrone, androstenedione, testosterone, methyltestosterone and dihydrotestosterone in waters of Suquía River at the same sampling sites than the present work, and all of them were below the limit of detection we decided not to measured estrogens and androgens.

\subsection{Fish collection}

Adult males of $C$. decemmaculatus were caught using hand fishing nets with a $2 \mathrm{~mm}$ mesh at each sampling site and at the same time as the water samples were taken. Fish were transported alive to the laboratory and killed by an overdose of tricaine methanolsulfonate (MS-222, Sigma-Aldrich). The standard length $(\mathrm{SL}, \mathrm{mm})$ and weight $\left(\mathrm{W}_{\mathrm{T}}, \mathrm{g}\right)$ were taken from each individual in order to estimate the Fulton Condition Factor $\left(\mathrm{K}=\left[\mathrm{W}_{\mathrm{T}} / \mathrm{SL}^{3}\right] \times 100,000\right)$ (Ricker, 1975).

Each fish was dissected and liver and gonads were removed and weighted. The Hepatosomatic Index $\left(\mathrm{HSI}=\left[\mathrm{W}_{\mathrm{L}} / \mathrm{W}_{\mathrm{T}} \mathrm{M}\right] \times 100 \%\right)$ (where $\mathrm{W}_{\mathrm{L}}$ is the weight of liver) and the Gonadosomatic Index
$\left(\mathrm{GSI}=\left[\mathrm{W}_{\mathrm{G}} / \mathrm{W}_{\mathrm{T}}\right] \times 100 \%\right)\left(\right.$ where $\mathrm{W}_{\mathrm{G}}$ is the weight of gonads $)$ were determined (Strange, 1996).

\subsection{Morphological analysis of the gonopodium}

The gonopodium of each male was examined under a stereoscopic microscope and photographed. To measure the gonopodium length (GL) each photographs was analyzed through the Image J software $\mathrm{v}$. 1.49 (Rasband, 2012). A Gonopodium Somatic Index (Gonop-SI = [GL $\times 100$ ] $/ \mathrm{SL}$ ) was calculated to estimate the gonopodium relative length to the standard length (Hued et al., 2013); the length of gonopodial filament $\left(\mathrm{G}_{\mathrm{FL}}\right)$ located at distal tip of the gonopodium was also measured (Fig. 2).

Clearing and staining procedures were carried out in order to observe the internal bone structure of each gonopodium following Rawson et al. (2006), but modified in the present study for $C$. decemmaculatus. Briefly, fish were preserved in $10 \%$ formalin and soaked into water for $2 \mathrm{~h}$ to rehydrate the tissue. The skin and internal organs were removed, and the fins and skeletal system were left intact. Then, each specimen was placed in $1 \%$ potassium hydroxide $(\mathrm{KOH})$ solution to remove the soft tissue from the skeleton. After $24 \mathrm{~h}, \mathrm{KOH}$ solution was replaced with $1 \%$ Alizarin red $\mathrm{S}$ for $6 \mathrm{~h}$ until bones were distinctly red. Finally, the skeleton were preserved in glycerol and examined with the stereomicroscope and photographed in order to measure the length of the fourth and sixth rays of the anal fin. Changes in the relationship between their lengths indicate alterations of the gonopodium structure, due to its development occurs with the complete elongation of the anal fin rays 3,4 , and 5 . Therefore, it was estimated the ratio of the lengths of rays 4 and 6 (4:6 length ratio) to

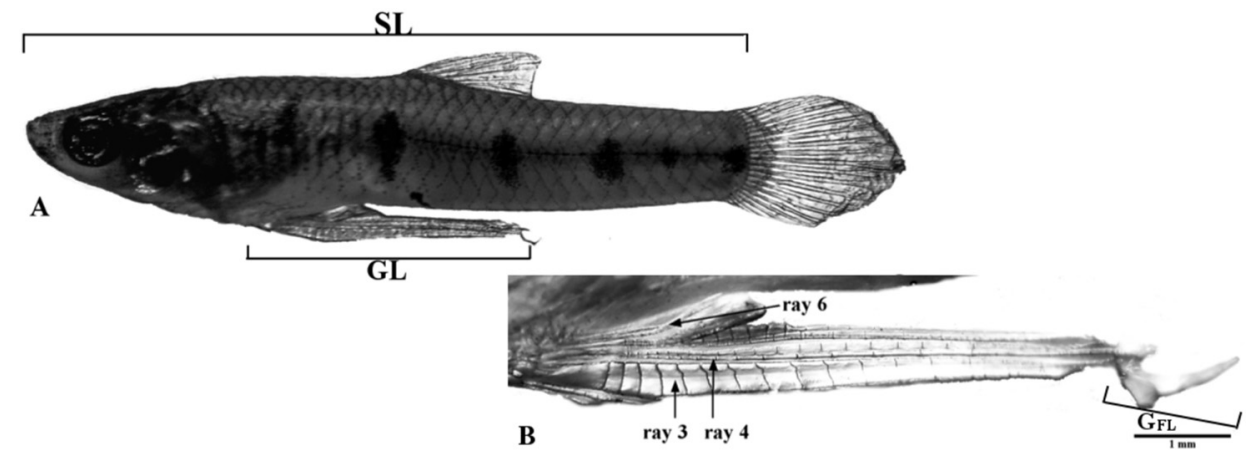

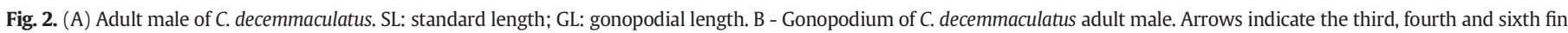
rays, GFL: length of the gonopodial filament. 
Table 1

Importance factor (W) assigned to liver histological alterations for each reaction pattern according to Bernet et al. (1999).

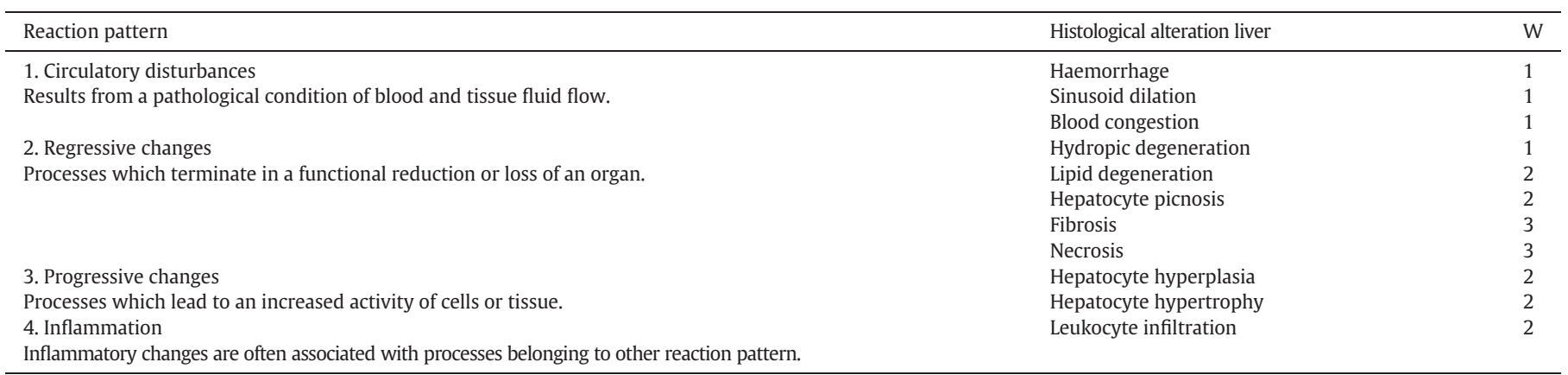

provide an index of elongation of gonopodium development (Fig. 2) (Doyle and Lim, 2002). The ratio of the thickness of ray 3 to that of ray 4 (3:4 thickness ratio) was also calculated to give a measure of the degree of gonopodium thickening (Fig. 2). While Doyle and Lim (2002) measured the thickness of the gonopodium at the sixth segment, we decided to measure it at the third segment due to its ease to be observed in the stereoscopic microscope. The presence or absence of hooks on the distal portion of ray 4 were also registered and counted on each individual (Fig. 2). These hooks act as holdfast devices during copulation, and their presence on the gonopodial tip indicates that gonopodium has fully developed (Turner, 1947).

\subsection{Histological analysis}

Liver and gonads were processed through routine histological techniques (Humason, 1972). Briefly, each tissue was dehydrated through an ethanol graded series, cleared in xylene and embedded in paraffin. Then, they were fully sectioned with a microtome at 4-6 $\mu \mathrm{m}$, mounted in microscope slides and stained with hematoxylin and eosin (H\&E). Each slide was examined with a light microscope (Olimpus $\mathrm{Cx}-31$ ) and photographed with a digital camera (Moticam $\left.{ }^{\circledR}\right)$.

In order to estimate the number and extension of a histopathological alteration, each liver slide was divided into 5 equal areas and analyzed at $40 \times$ power magnification. For gonads histological analysis, the cysts were identified at different stages of development and the percentage of primary stages cysts (which includes spermatogonia and spermatocytes) and secondary stages cyst (which includes spermatids and spermatozoa) were estimated. The histological alterations in testes were also recorded.

We applied a standardized assessment tool proposed by Bernet et al. (1999) and adapted by our research group in a previous work (Rautenberg et al., 2015) in order to evaluate the histological condition of each organ. This methodology consists in the calculation of a set of semiquantitave histopathological indices based on two main concepts: an importance factor $(w)$ that indicates the importance of a lesion according to its pathological relevance and how it affects the organ function and the ability of fish to survive; and a score value (a), which represents the degree and extent of an alteration. Furthermore, each histological lesion was classified into one of four reaction patterns: circulatory disturbances, inflammation, regressive changes, and progressive changes. Table 1 lists the reaction patterns and their specific alteration for liver.

An importance factor was assigned to each alteration if the importance is minimal ( $w=1$, the lesion is easily reversible as exposure to irritants ends), moderate ( $w=2$, the lesion is reversible in most cases if the stressor is neutralized), or severe ( $\mathrm{w}=3$, the lesion is generally irreversible, leading to the partial or total loss of the organ function). According to the degree and extension of each alteration, the liver areas analyzed were assessed using a score that ranges from 0 to 8 . The higher the score, the greater the area of damaged tissue (Table 2). After that, an index for a particular alteration was obtained from the multiplication of the score and the importance factor. The index for each reaction pattern was calculated by the sum of each alteration within a reaction pattern $\left(\mathrm{HI}_{\mathrm{Org} . \mathrm{Rp}}\right)$ and the sum of all the $\mathrm{HI}_{\text {Org.Rp }}$ gives an overall organ index $\left(\mathrm{HI}_{\mathrm{Liv}}=\right.$ liver histopathological index). The higher the index value, the greater the alteration of the liver.

\subsection{Statistical analysis}

In order to determine if the following dependent variables: WQI, K, HSI, GSI, Gonop-SI, $\mathrm{G}_{\mathrm{FL}}$, 4:6 length ratio, 3:4 thickness ratio, hooks, $\mathrm{HI}_{\text {LIV }}$, percentage of primary stages cysts and percentage of secondary stages cysts, differed significantly among sampling sites it was applied ANOVA test followed by a Tukey's multiple comparison test. Previously, the assumptions of normality and homogeneity of variance were testing using the Shapiro-Wilks test and Leven's test, respectively. When a

Table 2

Score value (a) which reflects the degree and extent of the each liver alteration according to Bernet et al. (1999) and adapted by Rautenberg et al. (2015)

\begin{tabular}{|c|c|c|c|c|c|c|}
\hline \multirow[t]{2}{*}{ Reaction pattern } & \multirow[t]{2}{*}{ Histological alterations } & \multicolumn{5}{|c|}{ Score value } \\
\hline & & 0 & 2 & 4 & 6 & 8 \\
\hline Circulatory disturbances & $\begin{array}{l}\text { Haemorrhage } \\
\text { Hepatocyte picnosis } \\
\text { Fibrosis } \\
\text { Necrosis }\end{array}$ & $0-1 \%$ & $1,1-10 \%$ & $10,1-20 \%$ & $20,1-30 \%$ & $>30 \%$ \\
\hline Regressive changes & Lipid degeneration & $0-5 \%$ & $5,1-15 \%$ & $15,1-25 \%$ & $25,1-50 \%$ & $>50 \%$ \\
\hline Inflammation & $\begin{array}{l}\text { Sinusoid dilation } \\
\text { Blood congestion } \\
\text { Hydropic degeneration }\end{array}$ & $0-5 \%$ & $5,1-25 \%$ & $25,1-50 \%$ & $50,1-75 \%$ & $>75 \%$ \\
\hline
\end{tabular}

0: unchanged, 2: low occurrence, 4: mild occurrence, 6: moderate occurrence, 8 : severe occurrence. 
variable did not meet these assumptions, a Kruskal-Wallis test (Sokal and Rohlf, 1995) was performed followed by Dunn's multiple comparison test. Significance was determined at alpha $=0.05$. All the analyses were performed using Infostat Software Package (Infostat, 2013).

\section{Results and discussion}

The negative impact of the water quality degradation affected the reproductive aspects of a native species fish of Suquía River Basin, Cnesterodon decemmaculatus. Changes in histological, morphological and somatic characteristics of the individuals along the environmental quality gradient determined the environmental and biological relevance of our work. Our results allowed us to provide tools that could be used as biomarkers in environmental assessments.

\subsection{Water quality assessment}

\subsubsection{Water quality index}

The water quality index (WQI) quantifies the general state of aquatic systems over a period of time and space through the measurement and subsequent mathematical transformation of physico-chemical and bacteriological parameters (Table 3). It summarized all this information in a dimensionless number through a percentage of water quality. The lowest values indicate the worst condition of an aquatic system (Pesce and Wunderlin, 2000).
In the present study the WQI varied significantly between sample sites (ANOVA, d.f. $=3, \mathrm{~F}=16.67 ; \mathrm{p}=0.01$ ) (Table 3). Upstream Cordoba city (PZ and CB) the mean WQI values were high (95.05 and $90.79 \%$, respectively), indicating almost pristine water conditions, whereas the area located downstream Córdoba City and the Waste Water Treatment Plant (VCM) presented the lowest mean WQI value (52.86\%). Since Hued et al. (2010) has indicated that index values close to $50 \%$ are hardly compatible with aquatic life, the value obtained in VCM showed the severe environmental degradation at this river section. On the other hand the sampling site located in the center of the city (PC) was characterized as moderately polluted (72.27\%). Although we did not carry out fish surveys in order to know the population status, it should be noted that fish captures in VCM involved a great sampling effort that only allowed capturing a low number of fish individuals. This observation agrees with that registered in previous studies which indicate that the total abundance of fish species decreases in highly polluted sites (Maggioni et al., 2012; Hued et al., 2013). On the other hand, at PC, no specimens of the $C$. decemmaculatus were collected at the end of the breeding season. At the same time, several fish species were caught so the absence of $C$. decemmaculatus was not due to water quality itself. However the reasons for the species absence remain unknown.

Cordoba City has a negative impact on water quality of Suquía River due to the constant population growth and the related anthropogenic activities causing a high degree of pollution. The high water quality degradation registered in VCM is mainly due to the presence of the wastewater-treatment plant, EDAR. This plant performs inadequate effluent

Table 3

Physico-chemical $\left(\mathrm{mg} \cdot \mathrm{L}^{-1}\right)$, bacteriological (UFC $\cdot 100 \mathrm{~mL}^{-1}$ ) parameters, water quality index (\%) and pesticides $\left(\mathrm{ng} \cdot \mathrm{L}^{-1}\right)$ measured in water samples collected along Suquía River.

\begin{tabular}{|c|c|c|c|c|c|c|c|c|}
\hline \multirow[t]{3}{*}{ Parameter } & \multicolumn{8}{|c|}{ Sampling sites } \\
\hline & \multicolumn{2}{|c|}{ Puente Zuviría } & \multicolumn{2}{|l|}{ Casa Bamba } & \multicolumn{2}{|l|}{ Puente Cantón } & \multicolumn{2}{|c|}{ V. Corazón María } \\
\hline & BBS & EBS & BBS & EBS & BBS & BS & BBS & EBS \\
\hline Dissolved oxygen & - & 9,90 & - & 8,90 & - & - & - & 6,50 \\
\hline N-nitrites & $3,61 \mathrm{E}-04$ & $<\mathrm{LOQ}$ & $3,61 \mathrm{E}-04$ & $<\mathrm{LOQ}$ & $1,05 E-03$ & - & 0,03 & 0,14 \\
\hline N-nitrates & 0,16 & 0,47 & 0,90 & 0,98 & 1,40 & - & 1,34 & 3,85 \\
\hline N-ammonia & 0,00 & 0,12 & 0,04 & 0,14 & 2,41 & - & 18,05 & 1,02 \\
\hline Sulfates & 0,00 & 10,48 & 3,58 & 13,62 & 23,65 & - & 55,41 & 64,89 \\
\hline Total phosphorus & 0 & - & 0 & - & 0,68 & - & 1,30 & - \\
\hline Total solids & 119,50 & 58,00 & 181,50 & 146,00 & 271,5 & - & 574,00 & 482,00 \\
\hline Dissolved solids & 88,83 & 48,00 & 91,20 & 69,00 & 253,00 & - & 458,89 & 338,00 \\
\hline Hardness & 69,42 & 46,36 & 125,53 & 73,20 & 120,78 & - & 201,61 & 236,68 \\
\hline Calcium & 21,73 & 31,72 & 36,21 & 61,00 & 36,59 & - & 65,94 & 168,36 \\
\hline Magnesium & 3,70 & 3,56 & 8,55 & 2,97 & 7,16 & - & 9,01 & 16,62 \\
\hline Chlorides & 4,88 & 9,90 & 8,79 & 11,89 & 20,50 & - & 166,94 & 55,47 \\
\hline Total colifoms & 240 & 15,00 & 38,00 & 245,00 & 3800,00 & - & $2,45 \mathrm{E}+06$ & $1,30 \mathrm{E}+06$ \\
\hline Faecal coliforms & - & 15,00 & - & 175,00 & - & - & - & $<\mathrm{LOQ}$ \\
\hline $5-\mathrm{DBO}$ & 1500 & 0,7 & 3,80 & 1,6 & - & - & - & 8,2 \\
\hline WQI & 97,6 & 92,5 & 92,4 & 89,17 & 72,27 & - & 58,63 & 47,08 \\
\hline \multicolumn{9}{|l|}{ Pesticides } \\
\hline Aldrin & $<$ LOD & $<$ LOD & $<\mathrm{LOD}$ & $<$ LOD & $<$ LOD & - & $<\mathrm{LOQ}$ & $<\mathrm{LOD}$ \\
\hline Dieldrin & $<\mathrm{LOD}$ & $<\mathrm{LOD}$ & $1,84 \pm 1,45$ & $<$ LOQ & $<\mathrm{LOQ}$ & - & $0,86 \pm 0,50$ & $<$ LOQ \\
\hline Endrin aldehyde & $<$ LOD & $<\mathrm{LOD}$ & $<$ LOD & $<\mathrm{LOD}$ & $<$ LOD & - & $0,90 \pm 0,50$ & $<$ LOD \\
\hline alfa Clordane & $<\mathrm{LOD}$ & $<\mathrm{LOD}$ & $<\mathrm{LOD}$ & $<\mathrm{LOQ}$ & $<\mathrm{LOD}$ & - & $<\mathrm{LOD}$ & $<\mathrm{LOD}$ \\
\hline alfa Hexachlorocyclohexane & $<$ LOQ & $<$ LOQ & $<$ LOD & $<\mathrm{LOQ}$ & $<$ LOD & - & $<$ LOD & $<\mathrm{LOD}$ \\
\hline d Hexachlorocyclohexane & $<$ LOQ & $<\mathrm{LOQ}$ & $<$ LOQ & $<\mathrm{LOQ}$ & $<\mathrm{LOQ}$ & - & $<$ LOQ & $<$ LOQ \\
\hline g Hexachlorocyclohexane & $<\mathrm{LOD}$ & $<$ LOQ & $<\mathrm{LOD}$ & $<\mathrm{LOQ}$ & $<\mathrm{LOD}$ & - & $<\mathrm{LOD}$ & $<\mathrm{LOQ}$ \\
\hline Chlorbenzilate & $<$ LOD & $<\mathrm{LOD}$ & $<$ LOQ & $<\mathrm{LOD}$ & $<$ LOD & - & $<$ LOD & $<\mathrm{LOD}$ \\
\hline Chlorothalonil & $<$ LOD & $<$ LOD & $<$ LOD & $<$ LOD & $<$ LOD & - & $<$ LOQ & $<$ LOQ \\
\hline Chlorpyrifos & $<\mathrm{LOD}$ & $2,98 \pm 2,66$ & $<\mathrm{LOD}$ & $3,13 \pm 2,83$ & $<\mathrm{LOD}$ & - & $<\mathrm{LOD}$ & $<\mathrm{LOD}$ \\
\hline cis Permethrin & $<$ LOD & $<$ LDO & $<$ LOD & $18,95 \pm 13,47^{*}$ & $<$ LOD & - & $8,27 \pm 1,72^{*}$ & $3,70 \pm 1,05^{*}$ \\
\hline trans Permethrin & $<$ LOD & $<$ LOD & $<$ LOD & $18,53 \pm 5,02^{*}$ & $8,54 \pm 9,29^{*}$ & - & $23,14 \pm 2,69^{*}$ & $19,07 \pm 5,35^{*}$ \\
\hline HCB-Hexachlorobenzene & $<$ LOD & $<\mathrm{LOD}$ & $<\mathrm{LOQ}$ & $3,20 \pm 2,55$ & $<\mathrm{LOQ}$ & - & $3,54 \pm 2,79$ & $<\mathrm{LOQ}$ \\
\hline Heptachlor & $<\mathrm{LOQ}$ & $<$ LOQ & $<\mathrm{LOD}$ & $<\mathrm{LOQ}$ & $<\mathrm{LOQ}$ & - & $<$ LOQ & $<$ LOQ \\
\hline Heptachlor epoxide & $<\mathrm{LOD}$ & $<\mathrm{LOD}$ & $<\mathrm{LOD}$ & $<\mathrm{LOD}$ & $<\mathrm{LOD}$ & - & $<\mathrm{LOD}$ & $<$ LOQ \\
\hline Propachlor & $<$ LOD & $<$ LOD & $<$ LOD & $<$ LOD & $9,71 \pm 10,63$ & - & $<$ LOD & $<\mathrm{LOD}$ \\
\hline Trifluralin & $<\mathrm{LOD}$ & $<$ LOD & $<$ LOD & $134,00 \pm 90,01^{*}$ & $<$ LOD & - & $<$ LOD & $<$ LOD \\
\hline
\end{tabular}

BBS: beginning of the breeding season, EBS: end of the breeding season, 5-DBO: 5-day biological oxygen demand, LOQ: lower than quantification limit, for the pesticides ranged from 0,2 to

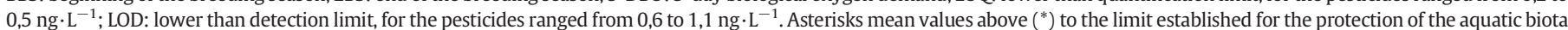

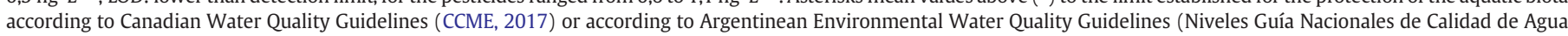
Ambiente) (SRHN, 2017). 
treatment or discharges wastewaters without previous treatment directly into the river, despite the self-purification capacity of the river is exceeded (Pesce and Wunderlin, 2000; Hued et al., 2010; Monferrán et al., 2011; Maggioni et al., 2012).

\subsubsection{Pesticides}

The registered pesticides as well as the concentrations measured indicate that fish, and aquatic biota in general, are subject to chronic exposure to substances of proven toxicity. Along the Suquía River basin we have registered several pesticides, such as organochlorines, organophosphates, permethrin and trifluralin, finding a high number of compounds at CB and VCM. Table 3 shows the concentration of each pesticide measured.

Trifluralin, found at $\mathrm{CB}$ at the end of the breeding season, was the most concentrated pesticide quantified ( $134 \mathrm{ng} \cdot \mathrm{L}^{-1}$ ), exceeding the $\mathrm{Ca}$ nadian Water Quality Guidelines (CCME, 2017) for aquatic biota protection in freshwater systems $\left(0.2 \mathrm{ng} \cdot \mathrm{L}^{-1}\right)$. This is a selective preemergence herbicide, which has been classified as highly toxic to fish, it has genotoxic potential, and negatively effects on the pituitary gland function (Könen and Çavaş, 2008; Silva et al., 2017).

Permethrin was also registered in high concentrations. This is a broad spectrum synthetic pyrethroid insecticide, used in agricultural, commercial and residential settings. This insecticide can cause oxidative stress and immunosuppressive effects in fish (Parent et al., 2011). In the beginning of the breeding season, the isomers cis and trans-permethrin were registered at PC and VCM, while at the end of the breeding season the isomers were registered at $\mathrm{CB}$ and VCM. In all these sites, the measured concentrations greatly exceed the limit of $0.6 \mathrm{ng} \cdot \mathrm{L}^{-1}$ established for the protection of the aquatic biota according to the Argentinean Environmental Water Quality Guidelines (SRHN, 2017).

Chlorpyrifos is an organophosphate insecticide commonly applied during the soybean cycle, which can affect behavioral, neurological and reproductive parameters in fish (Botté et al., 2012; De Silva and Samayawardhena, 2005; Oruç, 2010). In this regard, Bonifacio et al. (2016, 2017) have assess the effects of chlorpyrifos on $C$. decemmaculatus, and found a decrease in condition factor, alterations in the locomotor activity and significant variations in the activity of diverse enzymes, such as acetylcholinesterase, antioxidant and biotransformation enzymes. In our work, this insecticide was detected at low concentrations at $\mathrm{PZ}$ and $\mathrm{CB}$ (2.98 and $3.13 \mathrm{ng} \cdot \mathrm{L}^{-1}$, respectively), at the end of the breeding season.

Organochlorine pesticides such as aldrin, dieldrin, endrine and hexaclorobenzeno (HCB) are characterized by their high lipophilicity and high bioaccumulative potential. They are also compounds that can have hormone-disruptive effects as a result of their mimic action of estrogens (Tyler et al., 1998). Although the production and use of these substances has been banned worldwide, they are still detected in the environment due to their high persistence in sediments (Yang et al., 2015). In this regard, in the beginning of the breeding season, aldrin was registered at $\mathrm{PC}$, dieldrin and $\mathrm{HCB}$ were measured at $\mathrm{CB}, \mathrm{PC}$ and VCM and endrin at VCM. In the end of the breeding season only dieldrin and $\mathrm{HCB}$ were measure at $\mathrm{CB}$ and VCM. In all sites these pesticides were found in low concentrations.

\subsection{Body condition assessment}

The Fulton's condition factor $(\mathrm{K})$, showed the highest values during the end of the breeding season, at PZ and VCM (Table 4). The reproductive season coincides with the rainy season (spring and summer) where high temperatures and longer photoperiod predominate, causing a high availability of food for fish. In addition, we found significant differences between sampling sites, with lower values at VCM, at the beginning of the breeding season. These results indicate a direct relation with the high environmental degradation of VCM, which causes the deterioration of fish health. Length-based condition indices have been traditionally used to describe the general fish health. In this sense, individuals
Table 4

Somatic indices for $C$. decemmaculatus males collected along the Suquía River basin.

\begin{tabular}{|c|c|c|c|c|}
\hline \multicolumn{5}{|c|}{ Beginning of the breeding season } \\
\hline \multirow[t]{3}{*}{ Indices } & \multicolumn{4}{|l|}{ Sampling sites } \\
\hline & Puente Zuviría & Casa Bamba & Puente Cantón & V. Corazón María \\
\hline & $(\mathrm{n}=16)$ & $(n=13)$ & $(\mathrm{n}=17)$ & $(\mathrm{n}=18)$ \\
\hline $\mathrm{SL}(\mathrm{mm})$ & $20,49 \pm 0,35$ & $18,54 \pm 0,37$ & $19,8 \pm 0,34$ & $19,81 \pm 0,33$ \\
\hline $\mathrm{W}_{\mathrm{T}}(\mathrm{g})$ & $0,13 \pm 0,01$ & $0,09 \pm 0,01$ & $0,11 \pm 0,01$ & $0,11 \pm 0,01$ \\
\hline $\mathrm{K}$ & $1,45 \pm 0,03^{\mathrm{ab}}$ & $1,56 \pm 0,03^{a}$ & $1,42 \pm 0,03^{b}$ & $1,39 \pm 0,03^{b}$ \\
\hline HSI & $0,31 \pm 0,11^{\mathrm{a}}$ & $0,45 \pm 0,12^{\mathrm{a}}$ & $0,72 \pm 0,09^{\mathrm{ab}}$ & $0,94 \pm 0,10^{\mathrm{b}}$ \\
\hline GSI & $2,12 \pm 0,25^{*}$ & $1,86 \pm 0,27^{*}$ & $2,33 \pm 0,23$ & $2,54 \pm 0,27^{*}$ \\
\hline
\end{tabular}

End of the breeding season

\begin{tabular}{|c|c|c|c|c|}
\hline \multirow[t]{3}{*}{ Indices } & \multicolumn{4}{|l|}{ Sampling sites } \\
\hline & Puente Zuviría & Casa Bamba & Puente Cantón & V. Corazón María \\
\hline & $(\mathrm{n}=21)$ & $(\mathrm{n}=25)$ & & $(n=14)$ \\
\hline $\mathrm{SL}(\mathrm{mm})$ & $19,44 \pm 0,3$ & $20,26 \pm 0,27$ & - & $19,04 \pm 0,36$ \\
\hline $\mathrm{W}_{\mathrm{T}}(\mathrm{g})$ & $0,11 \pm 0,01$ & $0,13 \pm 0,01$ & - & $0,11 \pm 0,01$ \\
\hline K & $1,48 \pm 0,03^{*}$ & $1,55 \pm 0,03^{*}$ & - & $1,54 \pm 0,03^{*}$ \\
\hline HSI & $0,74 \pm 0,15^{*}$ & $0,9 \pm 0,15^{*}$ & - & $1,26 \pm 0,15^{*}$ \\
\hline GSI & $1,46 \pm 0,2$ & $1,78 \pm 0,2$ & - & $1,76 \pm 0,2$ \\
\hline
\end{tabular}

Values are expressed as means \pm SDs. Different letters ( $a$ and $b$ ), when shown, indicate significant differences among sampling sites $(\mathrm{p}<0.05)$. Asterisks indicate significant differences among reproductive seasons $(\mathrm{p}<0.05)$. SL: standard length, $\mathrm{W}_{\mathrm{T}}$ : weight $\mathrm{K}$ : Fulton condition factor, HSI: hepatosomatic index, GSI: gonadosomatic index.

with greater mass than their counterparts of similar length are considered to be in good condition (Rennie and Verdon, 2008; Arismendi et al., 2011). Therefore, the aforementioned will result in the amount of available energy that the individual possess which may be allocated to various life functions including reproduction, foraging and survival (Neff and Cargnelli, 2004). In particular, the Fulton's condition factor (K) could reflect the animal health condition, reproductive and non-reproductive season and food availability (Trudel et al., 2005; Froese, 2006). According to our results, fish from the most contaminated site must face the energetic costs related to the internal detoxifying processes of living in polluted waters, which can be observed through de decreased of K values in VCM.

Hepatosomatic Index (HSI), as well as the variation pattern of K, presented significant differences between sampling sites at the beginning of the breeding season (ANOVA, d.f. $=3, \mathrm{~F}=7.24, \mathrm{p}=0.002$ ). The highest HSI values correspond to VCM, the site with the lowest WQI values. The liver enlargement could be a nonspecific response to toxicants due to the increased demands on enzymatic activity in the liver (Toft et al., 2003). We also found significant differences in HSI values, between sampling periods (ANOVA, d.f. $=1, \mathrm{~F}=12.98, \mathrm{p}=0.0009$ ). The lowest values of this index occurred on November. Koya and Iwase (2004) indicated that during the spermatogenic period, at the beginning of the breeding season, the HSI of Gambusia affinis remains low due to the high energy demands that reproductive activities required, such as copulation. On the contrary, during the non-reproductive season, the HSI increases. These authors also describes that GSI presents an opposite pattern to HSI, showing the highest values during the spermatogenic period and a decrease as the reproductive season ends. In agreement with the mentioned work, in our study the GSI showed significant differences at the end and the beginning of the breeding season (ANOVA, d.f. $=1, \mathrm{~F}=7.80, \mathrm{p}=0.008$ ), with the lower values at the end of the reproductive period. These results suggest a gonadal depletion by the active copulation.

\subsection{Morphological analysis of the gonopodium}

The gonopodial development occurs under androgenic control during sexual maturation of males (Rosa-Molinar et al., 1994). This maturity could be morphologically identified through the presence of the 
so-called termination complex, consisting of hooks and serrae at the distal end of the gonopodium (Fig. 3). It has been shown that males living in waters contaminated by sewage effluents have gonopodia shorter than those living in unpolluted waters (Batty and Lim, 1999; Kinnberg and Toft, 2003; Hued et al., 2013). Similar observations have been recorded in males exposed to xenoestrogens during their development, under laboratory exposure conditions (Doyle and Lim, 2002; Angus et al., 2005).

Therefore, gonopodial development is sensitive to environmental chemicals through endocrine disruption (Kinnberg and Toft, 2003). However, as gonopodium once developed, it does not require more androgenic stimulation for its maintenance.

In the present study Gonop-SI showed significant differences between sampling sites, at the beginning of the breeding season, with the lowest values at PC (Table 5). This site, which is in the center of Cordoba city, receives the downtown runoff, which is composed largely by the pollution contribution coming from vehicles. In addition, it should be noted that in PC we have registered the presence of pesticides with a known estrogenic effect, such as dieldrin, HCB and b-hexachlorocyclohexane (Fry, 1995; Wester, 1991). Taking into account this situation, the decrease in Gonop-SI values could reflect the effects of degraded waters at this site on reproductive structures of fishes.

Maggioni et al. (2012) and Rautenberg et al. (2015) registered compounds with estrogenic activity in Suquía River basin once it leaves the city and receives the effluents from EDAR wastewater treatment plant. Some of these recorded compounds were heavy metals, such as lead, manganese and zinc. In our work we also determine the presence of various pesticides with potential ED effects. Thus, we expected to find a decreased in Gonop-SI values in individuals collected at VCM. However, the values we registered were similar to those of the individuals inhabiting the references sites. One possible explanation could be that fish at VCM are adapted to the altered environmental conditions of the aquatic system where they inhabit. When these conditions are constant over time and cover successive generations and traits that increase the success of individuals are inherited, genetic structure of the population could change, resulting in a population adaptation to the local conditions (Nacci et al., 1999). Another explanation to our results could be the contribution of new individuals from floods during the rainy season to the permanent population of VCM. These new individuals would not
Table 5

Gonopodium morphological parameters of $C$. decemmaculatus males collected along the Suquía River basin.

\begin{tabular}{|c|c|c|c|c|}
\hline \multicolumn{5}{|c|}{ Beginning of the breeding season } \\
\hline \multirow[t]{3}{*}{ Parameter } & \multicolumn{4}{|l|}{ Sampling sites } \\
\hline & Puente Zuviría & Casa Bamba & Puente Cantón & V. Corazón María \\
\hline & $(n=16)$ & $(n=13)$ & $(n=17)$ & $(n=18)$ \\
\hline $\mathrm{GL}(\mathrm{mm})$ & $7,93 \pm 0,13$ & $8,03 \pm 0,12$ & $7,65 \pm 0,12$ & $7,93 \pm 0,16$ \\
\hline Gonop-SI & $40,9 \pm 0,5$ & $39,69 \pm 0,46$ & $38,68 \pm 0,51^{b}$ & $40,98 \pm 0,64$ \\
\hline $\mathrm{G}_{\mathrm{FL}}(\mathrm{mm})$ & $1,08 \pm 0,06^{\mathrm{ab}}$ & $1,21 \pm 0,06^{\mathrm{b}}$ & $0,98 \pm 0,08$ & $0,94 \pm 0,08^{\mathrm{a}}$ \\
\hline 4:6 length ratio & $2,51 \pm 0,07^{\mathrm{a}}$ & $2,88 \pm 0,07^{b}$ & $2,89 \pm 0,06^{b}$ & $2,83 \pm 0,06^{\mathrm{b}}$ \\
\hline $3: 4$ width ratio & $6,48 \pm 0,43^{a}$ & $6,18 \pm 0,43^{\mathrm{ab}}$ & $5,29 \pm 0,37^{\mathrm{ab}}$ & $4,99 \pm 0,37^{\mathrm{b}}$ \\
\hline Hooks & $5,17 \pm 0,35$ & $5,17 \pm 0,35$ & $5,00 \pm 0,30$ & $5,63 \pm 0,30$ \\
\hline \multicolumn{5}{|c|}{ End of the breeding season } \\
\hline \multirow[t]{3}{*}{ Parameter } & \multicolumn{4}{|l|}{ Sampling sites } \\
\hline & Puente Zuviría & Casa Bamba & Puente Cantón & V. Corazón María \\
\hline & $(\mathrm{n}=21)$ & $(\mathrm{n}=25)$ & & $(\mathrm{n}=14)$ \\
\hline $\mathrm{GL}(\mathrm{mm})$ & $7,93 \pm 0,13$ & $8,03 \pm 0,12$ & - & $7,93 \pm 0,16$ \\
\hline Gonop-SI & $40,9 \pm 0,5$ & $39,69 \pm 0,46$ & - & $40,98 \pm 0,64$ \\
\hline $\mathrm{G}_{\mathrm{FL}}(\mathrm{mm})$ & $1,08 \pm 0,06^{\mathrm{ab}}$ & $1,21 \pm 0,06^{\mathrm{b}}$ & - & $0,94 \pm 0,08^{a}$ \\
\hline $4: 6$ length ratio & $2,95 \pm 0,06$ & $2,85 \pm 0,05$ & - & $2,96 \pm 0,08$ \\
\hline $3: 4$ width ratio & $5,44 \pm 0,18$ & $5,31 \pm 0,16$ & - & $5,04 \pm 0,24$ \\
\hline Hooks & $5,23 \pm 0,32$ & $5,69 \pm 0,29$ & - & $4,86 \pm 0,44$ \\
\hline
\end{tabular}

Values are expressed as means \pm SDs. Different letters ( $a$ and $b$ ), when shown, indicate significant differences among sampling sites $(\mathrm{p}<0.05)$. GL: gonopodium length, GonopSI: gonopodium somatic index, $\mathrm{G}_{\mathrm{FL}}$ : length of gonopodial filament.

have been exposed to the effluents discharged by EDAR treatment plant during their sexual maturation. Currently, our work group is carrying out genetic studies on $C$. decemmaculatus that could answer this question and allow us to know in more detail the population variations of this fish along Suquía River Basin. Additionally, it was measured the gonopodial filament of the third ratio $\left(\mathrm{G}_{\mathrm{FL}}\right)$. It is a bone process called cirri covered by soft tissue (Fig. 3), which is an effective tool to limit the depth of the gonopodium insertion during copulation, since the cirri could not be introduced in the genital pore of female. However this long and flexible processes serve to seal the genital pore of $C$. decemmaculatus females when the contact is made, and then avoiding

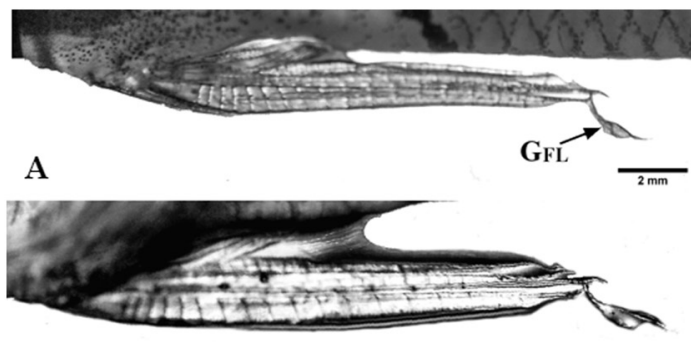

C

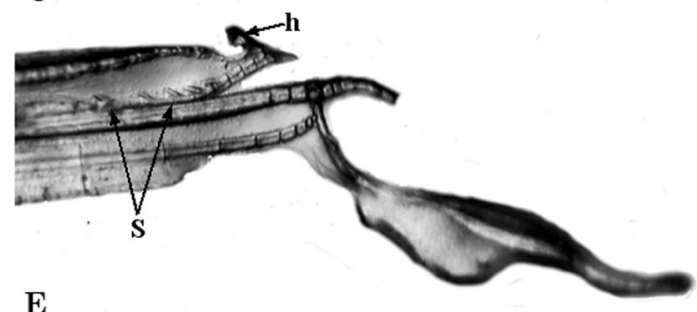

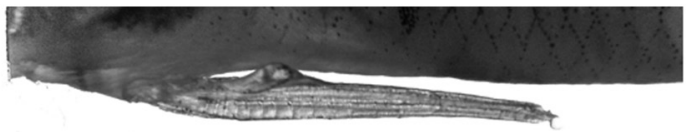

B

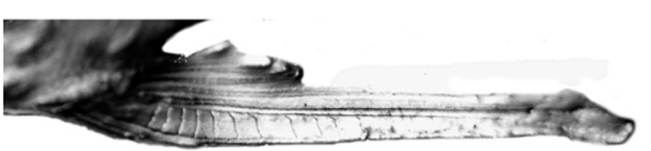

D

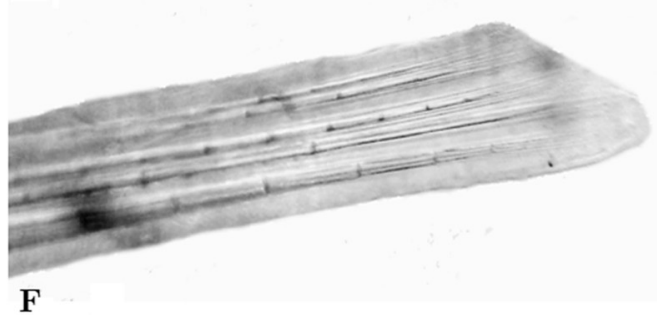

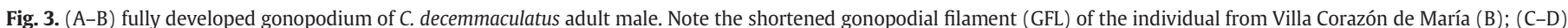

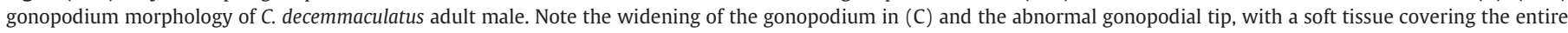

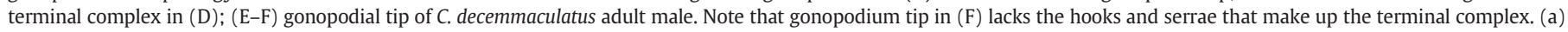
gonopodial tip with hook $(\mathrm{H})$ and serrae $(\mathrm{S})$. ( $\mathrm{A}$ and $\mathrm{B}=20 \times, \mathrm{C}$ and $\mathrm{D}=30 \times, \mathrm{E}$ and $\mathrm{F}=50 \times$ ). 
the loss of spermatozeugmata (sperm packets formed by the association of a Sertoli cell with spermatozoa) that are transferred during copulation (Greven, 2005; Uribe et al., 2014).

The $G_{F L}$ values differed significantly between sampling sites (ANOVA, d.f. $=3, \mathrm{~F}=3.67, \mathrm{p}=0.014$ ). Males coming from CB presented the highest values of $\mathrm{G}_{\mathrm{FL}}$ whereas individuals collected in VCM showed the lowest values of this parameter, at the end of the breading season.

These results indicate that although the length and maturation of gonopodia are within normal values at VCM, the internal structure is affected. The alterations observed in the bony cirri, such as its shortening, indicate the presence of anomalies in the small internal structures of the gonopodium. These significant differences present the same pattern of variations of the results obtained in the ANOVA test performed for the WQI, where significant differences were found between sample sites.

Moreover, females collected at the same time and at the same sampling sites, for a concurrent study, did not presented significant differences in the number of fertilized oocytes between sampling sites along Suquía River (Rautenberg et al., 2017). This finding suggests that the filament shortening registered in males does not affect the number of fertilized oocytes in females. On the other hand, individuals collected at $\mathrm{CB}$ during the beginning of the breading season presented the distal filament with a shorter length than those collected on the following sampling season at the same site. These fish also had a shorter standard length and total body weight and their gonopodium was shorter than those individuals that belong to the late reproductive period. These results suggest a maturation delay and not necessarily the toxic effects of polluted environments on the exposed fishes.

In the stained skeletons, the number of hooks present in the distal end of the fourth ray did not present significant differences (Kruskal-Wallis test, d.f. $=3, \mathrm{H}=3.17, \mathrm{p}=0.299$ ), indicating that individuals analyzed were sexually mature. On the other hand, the 4:6 length ratio showed significant differences between sampling sites during the beginning of the breading season (Table 5, Fig. 3). Fish individuals from $\mathrm{PZ}$ showed a lower ratio respect to the others sites. Angus et al. (2005) argues that a normal 4:6 length ratio in G. affinis mature males is 2.50 . These authors indicate that values lower to 2.50 represent a feminized state of males, as they are close to the 1:1 ratio of female anal fin rays. Individuals sampled at the PZ presented a ratio of 2.51 in the beginning of the breeding season. Therefore, the ratio is within the expected normal values for mature males.

The 3:4 thickness ratio between sampling sites in individuals collected on the beginning of the breeding season was significantly different (ANOVA, d.f. $=3, \mathrm{~F}=3.48, \mathrm{p}=0.031$ ). Fish individuals at VCM showed the lowest values at both samplings periods. Although the normal thicknesses ratio of ray 3 and 4 in mature males of $C$.

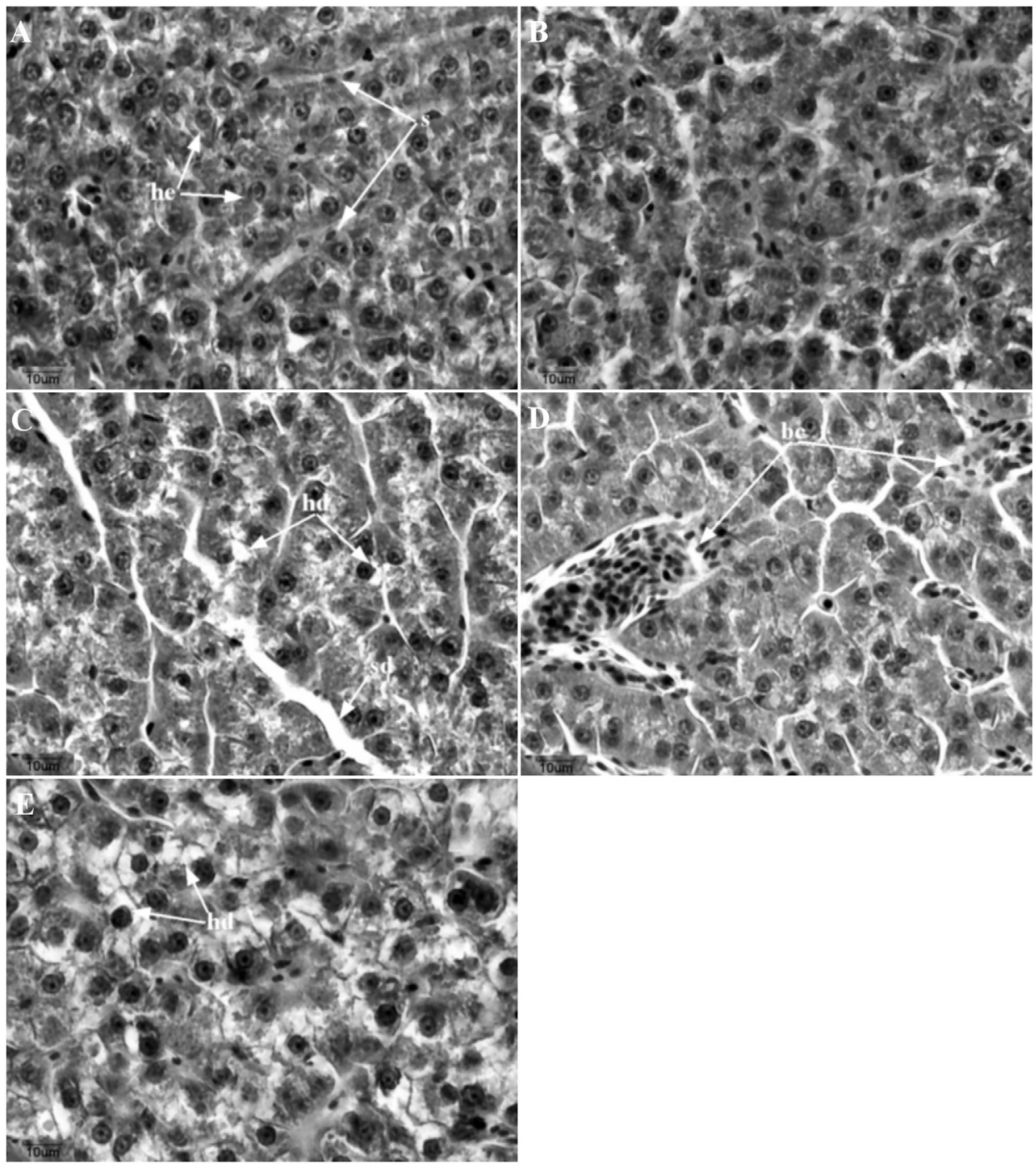

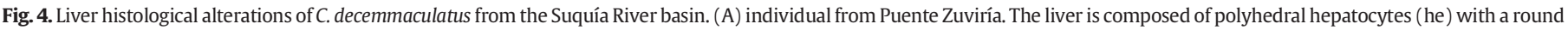

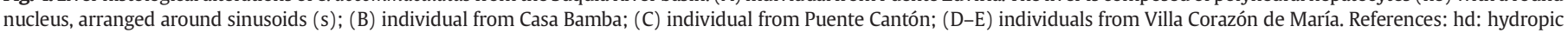
degeneration, sd: sinusoid dilation, bc: blood congestion (H\&E stain 400×). 
decemmaculatus had not been described until the present work, according to the data we obtained, the normal ratio would be close to 5 , since it is the minimum value that has been found in fishes from the reference sites. Thus, if this value is considered as an indicator of normality, the individuals collected from VCM would be within the expected parameters for the gonopodial 3:4 thickness ratio. According to our results, it becomes necessary to carry out new studies in order to know more about the correct development of gonopodium in C. decemmaculatus.

\subsection{Histological analysis}

\subsubsection{Liver}

As in many teleost, the liver of $C$. decemmaculatus has a homogenous parenchymal structure. Hepatocytes have a polyhedral shape, with a rounded nucleus. They are located around sinusoids and weakly organized in cords. The liver is the central organ of several key metabolic pathways and is associated with the processes of detoxification and biotransformation, being one of the most affected organs by the environmental pollutants (van der Oost et al., 2003; de la Torre et al., 2007). In response to exposure to different compounds, the liver could show alterations in its architecture, biochemistry and physiology that although are non-specific for the different class of pollutants, they allow to assess the general state of individuals (Costa et al., 2009; Ahmed et al., 2013).

In the present work, few liver histological alterations were registered (Fig. 4). We mainly registered regressive changes and circulatory disturbances, being hydropic degeneration and blood congestion, the most frequent alterations, respectively. Sinusoid dilation and scarce hepatocyte picnosis were also observed but to a lesser extent. Progressive changes or inflammation processes were not registered.

Hydropic degeneration is characterized by the presence of swollen cells with opaque, granular and more acidophilus cytoplasm than normal cells due to the accumulation of water inside them. Blood congestion involves an increased in blood flow, to ensure the detoxifying processes carried out by the hepatocytes. On the other hand, this event slows the circulation due to the increase of blood lacunas in the hepatic tissue (Fanta et al., 2003). This alteration has been associated with exposure to sublethal concentrations of several pesticides (Ballesteros et al., 2007; Hued et al., 2013). However, the low occurrence of these alterations in our study, suggests that the water quality degradation did not significantly affect the liver structure and function at the level analyzed.

Since no histological differences were found between the early and late reproductive periods, all individuals were considered together for the calculation of histopathological indices. HI LIV.Pr and HI LIV did not significantly vary between sampled sites (Kruskal-Wallis test, d.f. $=3$, $\mathrm{H}=1.7, \mathrm{p}=0.635$ ) (Table 6 ). These results could be related to the few alterations found during the histological analysis. Therefore, despite the severe pollution registered at VCM, the low frequency and severity of histological damages suggest that organism could be physiologically adapted to the adverse environmental conditions.

\subsubsection{Gonads}

C. decemmaculatus presents a restricted spermatogonial testis type, as well as the rest of Atherinomorpha (Grier et al., 1980). In this type of testis, lobules develop from the testicular periphery to the central

\section{Table 6}

Histopathological index in liver of $C$. decemmaculatus collected along Suquía River basin.

\begin{tabular}{|c|c|c|c|c|}
\hline \multirow[t]{3}{*}{ Parameter } & \multicolumn{4}{|l|}{ Sampling sites } \\
\hline & Puente Zuviría & Casa Bamba & Puente Canton & V. Corazón María \\
\hline & $(\mathrm{n}=5)$ & $(n=4)$ & $(n=4)$ & $(\mathrm{n}=6)$ \\
\hline $\mathrm{HI}_{\text {LIV }}$ & $20,77 \pm 1,41$ & $21,8 \pm 1,57$ & $19,75 \pm 1,57$ & $21,49 \pm 1,28$ \\
\hline
\end{tabular}

Values are expressed as means \pm SDs. duct. The cysts, which contain the spermatogenic cells, develop along the length of the lobule, with the spermatogonia being restricted to the termini of the lobules, near the albuginea tunic. As the spermatogenesis progresses, the cysts migrate towards the efferent ducts system and release the spermatozoa into them. Thereby, within the lobule, the different stages of spermatogenesis are in increasing order of maturation.

Spermatogonias A, surrounded by Sertoli cell processes, are located at the end of the lobule. Immediately next to them, there are the cysts containing spermatogonia B and immediately after, the primary and secondary spermatocytes are located, and finally it could be observed the spermatid and spermatozoid (Grier et al., 1980) (Fig. 5). In different fish species whit internal fertilization, spermatozoa are packaged in naked bundles, known as spermatozeugmata, that are released into the efferent duct (Uribe et al., 2014). The formation of spermatozeugmata always involves the association of Sertoli cells with the spermatozoa. In poeciliids, the sperm heads are associated with Sertoli cells so that they are all directed towards the periphery of the packaging (Fig. 5D), while their tails are oriented towards the center of the cysts (Uribe et al., 2014).

Although many compounds registered in the Suquía River basin could disrupt the endocrine system of fish, males collected along the watershed did not present testis histological alterations and the proportion of cysts with immature and mature stages did not significantly varied between sampling sites (Table 7).

Several works have pointed out changes of the normal testis structure under the exposure to EDs, showing both germinal and interstitial tissue abnormalities. Among the main disorders, it has been described an inhibition of spermatogenesis with an absence of spermatogenic cysts and the presence of spermatozoa in the lumina (Gimeno et al., 1998). Koç et al. (2012) also described spermatogonia anomalies such as loss of connection between these cells or syncytia formation, whereas Flammarion et al. (2000) and Kinnberg and Toft (2003) have also observed, in the efferent and seminifeous ducts, necrosis, fibrosis and hypertrophy of the Sertoli cells. Finally, several works have been showed ovo-testis development in males of different fish species such as Oryzias latipes, Rutilus rutilus and Cyprinus carpio, exposed to estrogenic chemicals (Gray and Metcalfe, 1997; Gimeno et al., 1998; Jobling and Tyler, 2003). Nevertheless, the results obtained from our work are in agreement with Angus et al. (2002), who maintain that poeciliids fishes appear to have a very stable sex determination.

According to our results $C$. decemmaculatus males are adapted to the degraded environmental conditions where they live, as they continue to reproduce at the most contaminated sites. However, it should be mentioned that in the last samplings carried out at VCM, the population was decreasing with respect to the first samplings, which coincides with the fluctuation in the abundance of the species in the most polluted sites described by Hued et al. (2010).

\section{Conclusions}

The increasing impact of the diverse anthropogenic activities on the aquatic environment is evident through the pollution gradient registered along the Suquía River basin. In particular, it is necessary to emphasize that $C$. decemmaculatus tolerates both pristine and highly polluted environments as could be observed through our work. However, individuals collected from contaminated sites were affected by the low quality of their waters. The analysis of the gonopodium morphology showed that males collected at Córdoba city had the lowest Gonopodium-Somatic Index value (Gonop-SI), while those from the most polluted site showed abnormalities in the small gonopodium structures. Therefore, the male copulatory organ of $C$. decemmaculatus is a good indicator of degraded aquatic environment. We considered that more studies that deepen on different aspects of their biology are needed, particularly those than consider the female reproductive aspects. The responses generated through the different biological parameters measured suggest that they could be used as good indicators of 

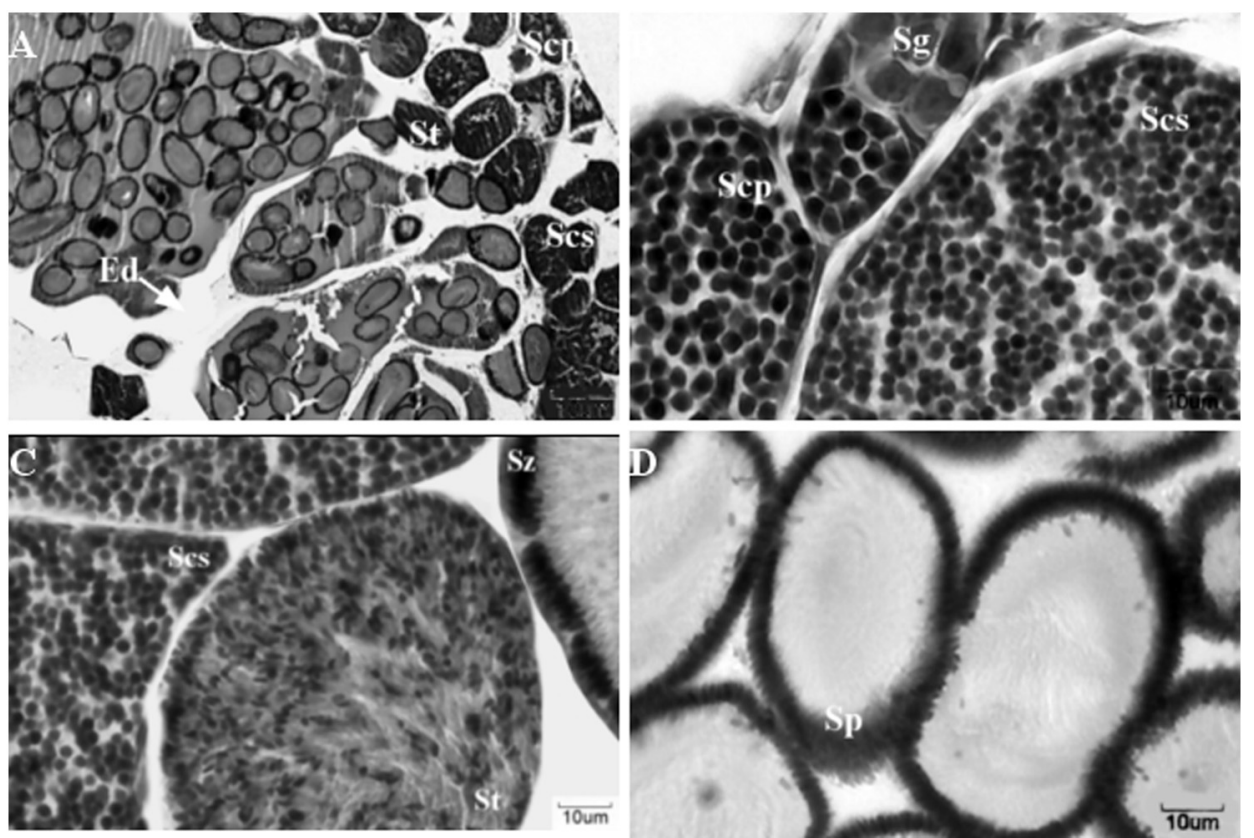

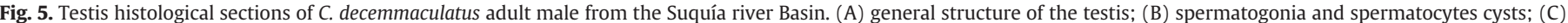

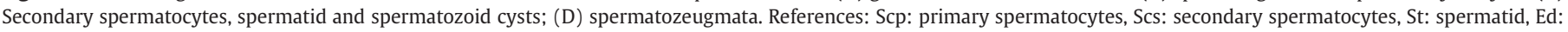
efferent duct, Sg: spermatog onia, Sp: spermatozeugmata (H\&E stain 400×).

Table 7

Percentage of primary and secondary spermatogenic cysts in C. decemmaculatus males collected in Suquía River.

\begin{tabular}{|c|c|c|c|c|}
\hline \multicolumn{5}{|c|}{ Beginning of the breeding season } \\
\hline \multirow[t]{3}{*}{ Parameter } & \multicolumn{4}{|l|}{ Sampling sites } \\
\hline & Puente Zuviría & Casa Bamba & Puente Cantón & V. Corazón María \\
\hline & $(\mathrm{n}=7)$ & $(\mathrm{n}=5)$ & $(n=6)$ & $(\mathrm{n}=7)$ \\
\hline$\%$ primary stages & $21,53 \pm 6,30$ & $15,67 \pm 7,46$ & $21,84 \pm 6,81$ & $21,37 \pm 6,30$ \\
\hline$\%$ secondary stages & $78,47 \pm 6,30$ & $84,33 \pm 7,46$ & $78,16 \pm 6,81$ & $78,63 \pm 6,30$ \\
\hline \multicolumn{5}{|c|}{ End of the breeding season } \\
\hline \multirow[t]{3}{*}{ Parameter } & \multicolumn{4}{|l|}{ Sampling sites } \\
\hline & Puente Zuviría & Casa Bamba & Puente Cantón & V. Corazón María \\
\hline & $(\mathrm{n}=4)$ & $(n=6)$ & & $(n=5)$ \\
\hline \% primary stages & $5,53 \pm 7,09$ & $8,63 \pm 5,79$ & - & $12,54 \pm 6,34$ \\
\hline$\%$ secondary stages & $94,47 \pm 6,73$ & $90,47 \pm 5,49$ & - & $86,02 \pm 6,02$ \\
\hline
\end{tabular}

Values are expressed as means \pm SDs.

water quality of an extensive South American area where $C$. decemmaculatus lives.

\section{Acknowledgments}

This work was supported by grants from National Research Council (CONICET, PIP 112-201101-01084), and the Secretariat of Science and Technology of the National University of Córdoba (SECyT, 2014-2015. Res no: 203/14). We would like to thank Manuel Fernando Sosa San Román for the elaboration of the graphical abstract. The manuscript was improved by the helpful comments from anonymous referees.

\section{References}

Ahmed, M.K., Habibullah-Al-Mamun, M., Parvin, E., Akter, M.S., Khan, M.S., 2013. Arsenic induced toxicity and histopathological changes in gill and liver tissue of freshwate fish, tilapia (Oreochromis mossambicus). Exp. Toxicol. Pathol. 65:903-909. https:// doi.org/10.1016/j.etp.2013.01.003.

Angus, R.A., McNatt, H.B., Howell, W.M., Peoples, S.D., 2001. Gonopodium development in normal male and 11-ketotestosterone-treated female mosquitofish (Gambusia affinis): a quantitative study using computer image analysis. Gen. Comp. Endocrinol. 123:222-234. https://doi.org/10.1006/gcen.2001.7669.

Angus, R.A., Weaver, S.A., Grizzle, J.M., Watson, R.D., 2002. Reproductive characteristics of male mosquitofish (Gambusia affinis) inhabiting a small southeastern U.S. river receiving treated domestic sewage effluent. Environ. Toxicol. Chem. 21:1404-1409. https://doi.org/10.1002/etc.5620210711.

Angus, R.A., Stanko, J., Jenkins, R.L., Watson, R.D., 2005. Effects of $17 \alpha$-ethynylestradiol on sexual development of male western mosquitofish (Gambusia affinis). Comp. Biochem. Physiol. C: Toxicol. Pharmacol. 140:330-339. https://doi.org/10.1016/j. cca.2005.03.008.

APHA (American Public Health Association), AWWA (American Water Works Association), WEF (Water Environment Federation), 1998. In: Eaton, A.D., Clesceri, L.S., Rice, E.W., Greenberg, A.H. (Eds.), Standard Methods for the Examination of Water and Wastewater, 20th ed. American Public Health Association, Washington, DC.

Arismendi, I., Penaluna, B., Soto, D., 2011. Body condition indices as a rapid assessment of the abundance of introduced salmonids in oligotrophic lakes of southern Chile. Lake Reservoir Manage. 27:61-69. https://doi.org/10.1080/ 07438141.2010 .536617$.

Arukwe, A., Goksøyr, A., 1998. Xenobiotics, xenoestrogens and reproduction disturbances in fish. Sarsia 83:225-241. https://doi.org/10.1080/00364827.1998.10413684.

Ballesteros, M.L., Bianchi, G.E., Carranza, M., Bistoni, M.A., 2007. Endosulfan acute toxicity and histomorphological alterations in Jenynsia multidentata (Anablepidae, Cyprinodontiformes). J. Environ. Sci. Health B 42:351-357. https://doi.org/10.1080/ 10934520601144659. 
Batty, J., Lim, R., 1999. Morphological and reproductive characteristics of male mosquitofish (Gambusia affinis holbrooki) inhabiting sewage-contaminated waters in New South Wales, Australia. Arch. Environ. Contam. Toxicol. 36:301-307. https:// doi.org/10.1007/s002449900475.

Bernet, D., Schmidt, H., Meier, W., Burkhardt-Holm, P., Wahli, T., 1999. Histopathology in fish: proposal for a protocol to assess aquatic pollution. J. Fish Dis. 22:25-34. https:// doi.org/10.1046/j.1365-2761.1999.00134.x.

Bonansea, R.I., Amé, M.V., Wunderlin, D.A., 2013. Determination of priority pesticides in water samples combining SPE and SPME coupled to GC-MS. a case study: Suquía River basin (Argentina). Chemosphere 90:1860-1869. https://doi.org/10.1016/j. chemosphere.2012.10.007.

Bonifacio, A.F., Cazenave, J., Bacchetta, C., Ballesteros, M.L., de los Ángeles Bistoni, M., Amé, M.V., Bertrand, L., Hued, A.C., 2016. Alterations in the general condition, biochemical parameters and locomotor activity in Cnesterodon decemmaculatus exposed to commercial formulations of chlorpyrifos, glyphosate and their mixtures. Ecol. Indic. 67: 88-97. https://doi.org/10.1016/j.ecolind.2016.02.011.

Bonifacio, A.F., Ballesteros, M.L., Bonansea, R.I., Filippi, I., Amé, M.V., Hued, A.C., 2017. Environmental relevant concentrations of a chlorpyrifos commercial formulation affect two neotropical fish species, Cheirodon interruptus and Cnesterodon decemmaculatus. Chemosphere https://doi.org/10.1016/j.chemosphere.2017.08.156.

Bortone, S.A., Davis, W.P., 1994. Fish intersexuality as indicator of environmental stress. Bioscience https://doi.org/10.2307/1312253.

Botté, E.S., Jerry, D.R., Codi King, S., Smith-Keune, C., Negri, A.P., 2012. Effects of chlorpyrifos on cholinesterase activity and stress markers in the tropical reef fish Acanthochromis polyacanthus. Mar. Pollut. Bull. 65:384-393. https:/doi.org/10.1016/ j.marpolbul.2011.08.020.

CCME (Canadian Council of Ministers of the Environment), 2017. Water quality guidelines for the protection of aquatic life. Canadian Environmental Quality Guidelines URL. http://ceqg-rcqe.ccme.ca/.

Contardo-Jara, V., Galanti, L.N., Amé, M.V., Monferrán, M.V., Wunderlin, D.A., Wiegand, C., 2009. Biotransformation and antioxidant enzymes of Limnoperna fortunei detect site impact in watercourses of Córdoba, Argentina. Ecotoxicol. Environ. Saf. 72: 1871-1880. https://doi.org/10.1016/j.ecoenv.2009.07.001.

Costa, P.M., Diniz, M.S., Caeiro, S., Lobo, J., Martins, M., Ferreira, A.M., Caetano, M., Vale, C., DelValls, T. Ángel, Costa, M.H., 2009. Histological biomarkers in liver and gills of juvenile Solea senegalensis exposed to contaminated estuarine sediments: a weighted indices approach. Aquat. Toxicol. 92:202-212. https://doi.org/10.1016/j. aquatox.2008.12.009.

De Silva, P.M.C.S., Samayawardhena, L.A., 2005. Effects of chlorpyrifos on reproductive performances of guppy (Poecilia reticulata). Chemosphere 58:1293-1299. https:// doi.org/10.1016/j.chemosphere.2004.10.030.

van der Oost, R., Beyer, J., Vermeulen, N.P.E., 2003. Fish bioaccumulation and biomarkers in environmental risk assessment: a review. Environ. Toxicol. Pharmacol. 13, 57-149.

Doyle, C.J., Lim, R.P., 2002. The effect of $17 \beta$-estradiol on the gonopodial development and sexual activity of Gambusia holbrooki. Environ. Toxicol. Chem. 21, $2719-2724$.

Fanta, E., Rios, F.S.A., Romão, S., Vianna, A.C.C., Freiberger, S., 2003. Histopathology of the fish Corydoras paleatus contaminated with sublethal levels of organophosphorus in water and food. Ecotoxicol. Environ. Saf. 54:119-130. https://doi.org/10.1016/ S0147-6513(02)00044-1.

Fausch, K.D., Lyons, J., Karr, J.R., Angermeier, P.L., 1990. Fish communities as indicators of environmental degradation. Am. Fish. Soc. Symp. 8. American Fisheries Society Symposium, pp. 123-144.

Flammarion, P., Brion, F., Babut, M., Garric, J., Migeon, B., Noury, P., Thybaud, E., Palazzi, X., Tyler, C.R., 2000. Induction of fish vitellogenin and alterations in testicular structure: preliminary results of estrogenic effects in chub (Leuciscus cephalus). Ecotoxicology 9, $127-135$.

Froese, R., 2006. Cube law, condition factor and weight-length relationships: history, meta-analysis and recommendations. J. Appl. Ichthyol. 22:241-253. https://doi.org/ 10.1111/j.1439-0426.2006.00805.x.

Fry, D.M., 1995. Reproductive effects in birds exposed to pesticides and industrial chemicals. Environ. Health Perspect. 103:165-171. https://doi.org/10.1289/ ehp.95103s7165.

Gimeno, S., Komen, H., Jobling, S., Sumpter, J., Bowmer, T., 1998. Demasculinisation of sexually mature male common carp, Cyprinus carpio, exposed to 4-tert-pentylphenol during spermatogenesis. Aquat. Toxicol. 43:93-109. https://doi.org/10.1016/S0166445X(98)00060-5

Gray, M.A., Metcalfe, C.D., 1997. Induction of testis - ova in Japanese Medaka (Oryzias latipes) exposed to p-nonylphenol. Environ. Toxicol. Chem. 16, 1082-1086.

Greven, H., 2005. Structural and behavioral traits associated with sperm transfer in poeciliinae. Viviparous Fishes, pp. 147-166.

Grier, H.J., Linton, J.R., Leatherland, J.F., De Vlaming, V.L., 1980. Structural evidence for two different testicular types in teleost fishes. Am. J. Anat. 159:331-345. https://doi.org/ 10.1002/aja.1001590307.

Hued, A.C., Bistoni, M.D.L.Á., 2005. Development and validation of a biotic index for evaluation of environmental quality in the central region of Argentina. Hydrobiologia 543:279-298. https://doi.org/10.1007/s10750-004-7893-1.

Hued, A., Dardanelli, S., Bistoni, M., 2010. Temporal and spatial variability of fish assemblages in a river basin with an environmental degradation gradient. Community Ecol. 11:41-50. https://doi.org/10.1556/ComEc.11.2010.1.7.

Hued, A.C., Lo Nostro, F.L., Wunderlin, D.A., Bistoni, M. de los Á., 2013. Reproductive impairment of a viviparous fish species inhabiting a freshwater system with anthropogenic impact. Arch. Environ. Contam. Toxicol. 64:281-290. https://doi.org/10.1007/ s00244-012-9826-8.

Humason, G.L., 1972. Animal Tissue Techniques. 3rd ed. W.H. Freeman, San Francisco, CA.
INDEC (Instituto Nacional de Estadísticas y Censos de la República Argentina), 2010. Censo Nacional de Población, Hogares y Viviendas 2010. URL. https://www.indec. gob.ar/censos_provinciales.asp.

Infostat, 2013. Grupo InfoStat. Facultad de Ciencias Agropecuarias, Universidad Nacional de Córdoba.

Jobling, S., Tyler, C.R., 2003. Endocrine disruption in wild freshwater fish. Pure Appl Chem. 75:2219-2234. https://doi.org/10.1351/pac200375112219.

Kinnberg, K., Toft, G., 2003. Effects of estrogenic and antiandrogenic compounds on the testis structure of the adult guppy (Poecilia reticulata). Ecotoxicol. Environ. Saf. 54: 16-24. https://doi.org/10.1016/S0147-6513(02)00010-6.

Koç, N.D., Akbulut, C., Kayhan, F.E., Kaymak, G., 2012. Histopathological changes in testis of the swordtail fish, Xiphophorus helleri (Pisces: Poecilidae) exposed to deltamethrin. Fresenius Environ. Bull. 21, 2866-2870.

Könen, S., Çavaş, T., 2008. Genotoxicity testing of the herbicide trifluralin and its commercial formulation Treflan using the piscine micronucleus test. Environ. Mol. Mutagen. 49:434-438. https://doi.org/10.1002/em.20401.

Koya, Y., Iwase, A., 2004. Annual reproductive cycle and rate of the spermatogenic process in male mosquitofish Gambusia affinis. Ichthyol. Res. 51:131-136. https://doi.org/ 10.1007/s10228-004-0208-8.

de la Torre, F.R., Salibián, A., Ferrari, L., 2007. Assessment of the pollution impact on biomarkers of effect of a freshwater fish. Chemosphere 68:1582-1590. https://doi.org/ 10.1016/j.chemosphere.2007.02.033.

Leusch, F.D.L., Chapman, H.F., Kay, G.W., Gooneratne, S.R., Tremblay, L.A., 2006. Anal fin morphology and gonadal histopathology in mosquitofish (Gambusia holbrooki) exposed to treated municipal sewage effluent. Arch. Environ. Contam. Toxicol. 50: 562-574. https://doi.org/10.1007/s00244-005-1040-5.

Lucinda, P.H.F., 2005. Systematics of the genus Cnesterodon Garman, 1895 (Cyprinodontiformes: Poeciliidae: Poeciliinae). Neotrop. Ichthyol. 3:259-270 https://doi.org/10.1590/S1679-62252005000200003.

Maggioni, T., Hued, A.C., Monferrán, M.V., Bonansea, R.I., Galanti, L.N., Amé, M.V., 2012 Bioindicators and biomarkers of environmental pollution in the middle-lower basin of the Suquía river (Córdoba, Argentina). Arch. Environ. Contam. Toxicol. 63: 337-353. https://doi.org/10.1007/s00244-012-9785-0.

Merlo, C., Abril, A., Amé, M.V., Argüello, G.A., Carreras, H.A., Chiappero, M.S., Hued, A.C. Wannaz, E., Galanti, L.N., Monferrán, M.V., González, C.M., Solís, V.M., 2011. Integral assessment of pollution in the Suquía River (Córdoba, Argentina) as a contribution to lotic ecosystem restoration programs. Sci. Total Environ. 409:5034-5045. https:// doi.org/10.1016/j.scitotenv.2011.08.037.

Monferrán, M.V., Galanti, L.N., Bonansea, R.I., Amé, M.V., Wunderlin, D.A., 2011. Integrated survey of water pollution in the Suquía River basin (Córdoba, Argentina). J. Environ. Monit. 13:398-409. https://doi.org/10.1039/COEM00545B.

Nacci, D., Coiro, L., Champlin, D., Jayaraman, S., McKinney, R., Gleason, T.R., Munns Jr., W. R., Specker, J.L., Cooper, K.R., 1999. Adaptations of wild populations of the estuarine fish Fundulus heteroclitus to persistent environmental contaminants. Mar. Biol. 134: 9-17. https://doi.org/10.1007/s002270050520.

Neff, B.D., Cargnelli, L.M., 2004. Relationships between condition factors, parasite load and paternity in bluegill sunfish, Lepomis macrochirus. Environ. Biol. Fish 71:297-304. https://doi.org/10.1007/s10641-004-1263-8.

Nimptsch, J., Wunderlin, D.A., Dollan, A., Pflugmacher, S., 2005. Antioxidant and biotransformation enzymes in Myriophyllum quitense as biomarkers of heavy metal exposure and eutrophication in Suquía River basin (Córdoba, Argentina). Chemosphere 61: 147-157. https://doi.org/10.1016/j.chemosphere.2005.02.079.

Oruç, E.Ö., 2010. Oxidative stress, steroid hormone concentrations and acetylcholinesterase activity in Oreochromis niloticus exposed to chlorpyrifos. Pestic. Biochem. Physiol. 96:160-166. https://doi.org/10.1016/j.pestbp.2009.11.005.

Parent, L.M., DeLorenzo, M.E., Fulton, M.H., 2011. Effects of the synthetic pyrethroid insecticide, permethrin, on two estuarine fish species. J. Environ. Sci. Health A 46:615-622. https://doi.org/10.1080/03601234.2011.589316.

Pasquini, A.I., Formica, S.M., Sacchi, G.A., 2012. Hydrochemistry and nutrients dynamic in the Suquía River urban catchment's, Córdoba, Argentina. Environ. Earth Sci. 65: 453-467. https://doi.org/10.1007/s12665-011-0978-z.

Pesce, S.F., Wunderlin, D.A., 2000. Use of water quality indices to verify the impact of Córdoba City (Argentina) on Suquía River. Water Res. 34:2915-2926. https://doi. org/10.1016/S0043-1354(00)00036-1.

Rasband, W.S., 2012. ImageJ. U.S. National Institutes of Health, Bethesda, Maryland, USA,1; 1997-2012. URL. http://imagej.nih.gov/ij/.

Rautenberg, G.E., Amé, M.V., Monferrán, M.V., Bonansea, R.I., Hued, A.C., 2015. A multilevel approach using Gambusia affinis as a bioindicator of environmental pollution in the middle-lower basin of Suquía River. Ecol. Indic. 48:706-720. https://doi.org/ 10.1016/j.ecolind.2014.09.025.

Rautenberg, G., Zambrano, M., Hued, A., 2017. Aspectos resproductivos de Cnesterodon decemmaculatus como indicadores de degradación ambiental. V Simposio Argentino de Ictiología. Corrientes. Argentina https://doi.org/ 10.13140/RG.2.2.27754.41925.

Rawson, C.A., Lim, R.P., Warne, M.J., Doyle, C.J., 2006. The effect of 17b-estradiol on the development of modified hemal spines in early-life stage Gambusia holbrooki. Arch. Environ. Contam. Toxicol. 51, 253-262.

Rennie, M.D., Verdon, R., 2008. Development and evaluation of condition indices for the lake whitefish. N. Am. J. Fish Manag. 28:1270-1293. https://doi.org/10.1577/M06-258.1.

Ricker, W.E., 1975. Computation and interpretation of biological statistics of fish populations. Bull. Fish. Res. Board Can. vol. 108. Department of the Environment, Fisheries and Marine Service, Ottawa, p. 382.

Rodrigues Capítulo, A., Gómez, N., Giorgi, A., Feijoó, C., 2010. Global changes in pampean lowland streams (Argentina): implications for biodiversity and functioning. Hydrobiologia 657:53-70. https://doi.org/10.1007/s10750-0100319-3. 
Rosa-Molinar, E., Hendricks, S.E., Rodriguez-Sierra, J., Fritzsch, B., 1994. Development of the anal fin appendicular support in the western mosquitofish, Gambusia affinis affinis (Baird and Girard, 1854): a reinvestigation and reinterpretation. Cells Tissues Organs 151:20-35. https://doi.org/10.1159/000147639.

Silva, J.M., Santos, F.L.B., Santos, R.V., Barreto, E.O., Santos, E.L., Goulart Santana, A.E Rodarte, R.S., Machado, S.S., Abreu, F.C., 2017. Determination of genotoxic effect of trifluralin on Colossoma macropomum (Teleostei: Characidae: Serrasalminae, Cuvier, 1816) using a multibiomarker approach. Ecotoxicol. Environ. Contam. 12:85-93. https://doi.org/10.5132/eec.2017.01.11.

Sokal, R., Rohlf, F., 1995. Biometry: The Principles and Practice of Statistics in Biological Research. 3rd ed. W.H. Freeman, New York, p. 880.

SRHN (Subsecretaría de Recursos Hídricos de la Nación), 2017. Niveles Guía Nacionales de Calidad de Agua Ambiente. Subsecretaría de Recursos Hídricos de la Nación, República Argentina URL. https://www.mininterior.gov.ar/obras-publicas/rhcalidad-niveles.php.

Strange, R.J., 1996. Field examination of fish. In: Murphy, B.R., Willis, D.W. (Eds.), Fisheries Techniques. American Fisheries Society, Bethesda, Maryland, pp. 443-446.

Toft, G., Edwards, T.M., Baatrup, E., Guillette, L.J., 2003. Disturbed sexual characteristics in male mosquitofish (Gambusia holbrooki) from a lake contaminated with endocrine disruptors. Environ. Health Perspect. 111:695-701. https://doi.org/10.1289/ ehp.6022.

Trudel, M., Trudel, M. Tucker, S., Tucker, S, Morris, JFT, Morris, JFT, Higgs, D. a, Higgs, D. a, Welch, D.W., Welch, D.W., 2005. Indicators of energetic status in juvenile Coho salmon and Chinook salmon. N. Am. J. Fish Manag. 25:374-390. https://doi.org/ 10.1577/M04-018.1.

Turner, C.L., 1947. The rate of morphogenesis and regeneration of the gonopodium in normal and castrated males of Gambusia-Affinis. J. Exp. Zool. 106, 125-143.
Tyler, C.R., Jobling, S., Sumpter, J.P., 1998. Endocrine disruption in wildlife: a critical review of the evidence. Crit. Rev. Toxicol. 28:319-361. https://doi.org/10.1080/ 10408449891344236.

Uribe, M.C., Grier, H.J., Mejía-Roa, V., 2014. Comparative testicular structure and spermatogenesis in bony fishes. Spermatogenesis 4, e983400. https://doi.org/10.4161/ 21565562.2014.983400.

Valdés, M.E., Amé, M.V., Bistoni, M.D.L.A., Wunderlin, D.A., 2014. Occurrence and bioaccumulation of pharmaceuticals in a fish species inhabiting the Suquía River basin (Córdoba, Argentina). Sci. Total Environ. 472:389-396. https://doi.org/10.1016/j. scitotenv.2013.10.124.

Wester, P.W., 1991. Histopathological effects of environmental pollutants $\beta-\mathrm{HCH}$ and methyl mercury on reproductive organs in freshwater fish. Comp. Biochem. Physiol. C Pharmacol. Toxicol. Endocrinol. 100:237-239. https://doi.org/10.1016/0742-8413 (91)90160-U.

Wolf, J.C., Dietrich, D.R., Friederich, U., Caunter, J., Brown, A.R., 2004. Qualitative and quantitative histomorphologic assessment of fathead minnow Pimephales promelas gonads as an endpoint for evaluating endocrine-active compounds: a pilot methodology study. Toxicol. Pathol. 32:600-612. https://doi.org/10.1080/01926230490515201.

Wunderlin, D.A., Díaz, M. del P., Amé, M.V., Pesce, S.F., Hued, A.C., Bistoni, M. de los Á. 2001. Pattern recognition techniques for the evaluation of spatial and temporal variations in water quality. A case study: Suquía River Basin (Córdoba-Argentina). Water Res. 35:2881-2894. https://doi.org/10.1016/S0043-1354(00)00592-3.

Yang, Y.Y., Toor, G.S., Williams, C.F., 2015. Pharmaceuticals and organochlorine pesticides in sediments of an urban river in Florida, USA. J. Soils Sediments 15:993-1004. https://doi.org/10.1007/s11368-015-1077-7. 